\title{
17
}

\section{Minimum wages and the remaking of the wage-setting systems in Greece and the UK}

\author{
Maria Karamessini and Damian Grimshaw
}

\section{Introduction}

The steady encroachment of a more neoliberal set of market principles among advanced capitalist countries has not necessarily been accompanied by a declining role of the state. This is as true with respect to the state's role in wagesetting as it is in other areas of economic governance, such as social transfers, product market regulation and corporate governance (Streeck, 2014). Since the economic crisis, government minimum wage policy has played an increasingly interventionist role in many countries, albeit with divergent goals, including responding to falling living standards, adjusting unit labour costs, compensating for falling welfare budgets and substituting for collective wage negotiation. Such interventions may adapt the minimum wage up or down, reflecting (and shaping) a constellation of competing interests and political and economic conditions, as well as pay equity goals (Grimshaw and Rubery, 2013; Rubery, 2003).

Theoretical ideas about the crowding out of participative wage-setting (Aghion et al., 2011), legitimation of marketisation processes (Koçer and Visser, 2009) and a neoliberal shift (e.g. Baccaro and Howell, 2011; Hermann, 2014; Hyman, 2015) are helpful in revealing both the underlying reasons for state interventions in minimum wage fixing and the interrelationship with national industrial relations systems and conditions of employment. In this chapter, we develop these ideas through a comparative empirical analysis of two countries that are to some extent at the opposite ends of Europe's minimum wage policy approaches observed since the economic crisis: Greece and the UK. 


\section{Minimum wage policy in Europe since the economic crisis}

At the onset of the global financial and economic crisis, 20 of the 27 European Union (EU) member states had a generally applicable statutory minimum wage. With Croatia, which joined the EU in 2013, and Germany, which adopted a national minimum wage in 2015, by 2016, 22 of the 28 EU member states possessed statutory minimum wage systems.

Since the beginning of the crisis, many countries have sought to contain the impact of minimum wages on average wage developments and labour costs, especially those where austerity policies were scrutinised by the Troika. However, a significant number of countries have continued to rely on minimum wage increases to conduct their wage policy (ILO, 2015a). The contrasting approaches reflect new momentum in old debates about the role of minimum wages in labour markets, fuelled by evidence of a slowdown in realwage growth, persistent high shares of working poor and long-run increases in earnings inequality (OECD, 2015). The introduction of a statutory minimum wage in Germany in 2015 further triggered debates across Europe, especially in countries without a statutory minimum wage (Eurofound, 2016). However, in most of these countries (for example, in Austria, Finland and Denmark) there was a consensus among the main actors to stick to the collectively agreed sector or occupational minima. In Italy, the government included the possibility of introducing a statutory minimum wage in the reform of its Jobs Act, but decided not to implement it for the time being, following criticism from the trade unions. In Cyprus, where a statutory minimum wage applies to nine occupations, the employer organisations insist that this should be abolished or drastically reduced (Eurofound, 2016). Although, the combination of sector minimum rates and high levels of collective bargaining coverage can, at least from a pay equity perspective, be regarded as a functional equivalent to a statutory national minimum wage (Garnero et al., 2015), the long-standing erosion of bargaining coverage well before the economic crisis, its significant retreat during the latter in many countries (ILO, 2015b) and the expansion of low-wage sectors in most economies bring minimum wage policy back on the European agenda.

The most important changes in minimum wage policy during the crisis took place in those EU countries that had to ask for financial assistance from international institutions. ${ }^{1}$ In exchange, they had to implement economic adjustment programmes dictated and supervised by their creditors. A key macroeconomic tool was to use minimum wage cuts as a mechanism to depress wage settlements through the whole economy. For example, Ireland reduced its hourly minimum 
wage by 1 euro (around 12 per cent) in early 2011 in response to Troika pressures, although quickly reversed this decision after strong union campaigns. The Greek government was pressured even further by the Troika and implemented a radical 22 per cent cut in its national minimum wage. Similarly, in implementation of their loan agreements, Latvia, Lithuania, Bulgaria, Portugal and Spain (as well as Greece and Ireland) all imposed freezes of their minimum wage for several years. All the above countries increased the minimum wage once the period of freeze was over - the last being Ireland in 2016 - while the freeze is still ongoing in Greece. This is why no other EU country except Greece has experienced a decrease in the nominal value of a minimum wage over the eightyear period 2008-16 (Figure 17.1).

It follows, therefore, that Europe witnessed contrasting trends in the real value of minimum wages. Of the 15 countries with trend data for 200815 (Figure 17.2), it increased significantly in eight (as much as 35 per cent in Poland), stagnated in six countries (Czech Republic, Spain, the UK,

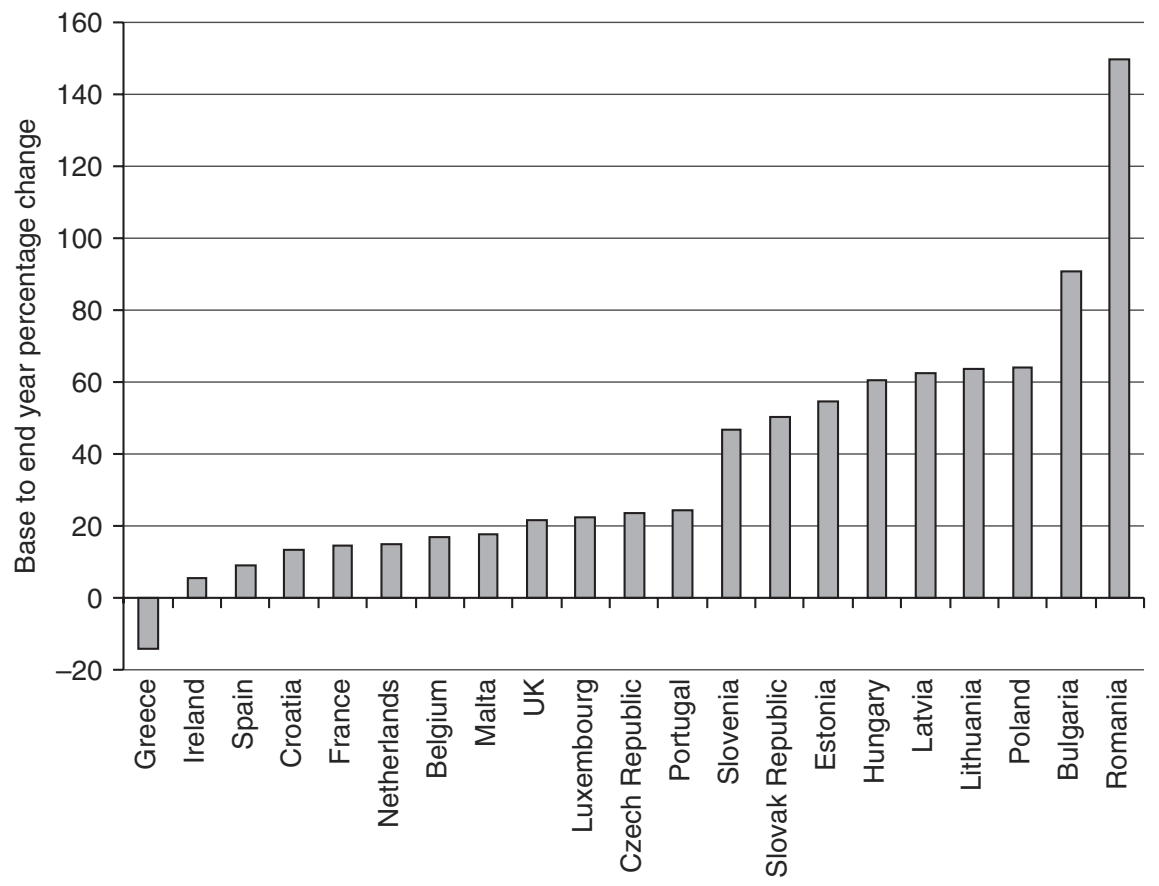

Figure 17.1 Change in monthly minimum wages at current prices, national currency 2008-16

Source: Eurostat database online (extracted 21 August 2016). 


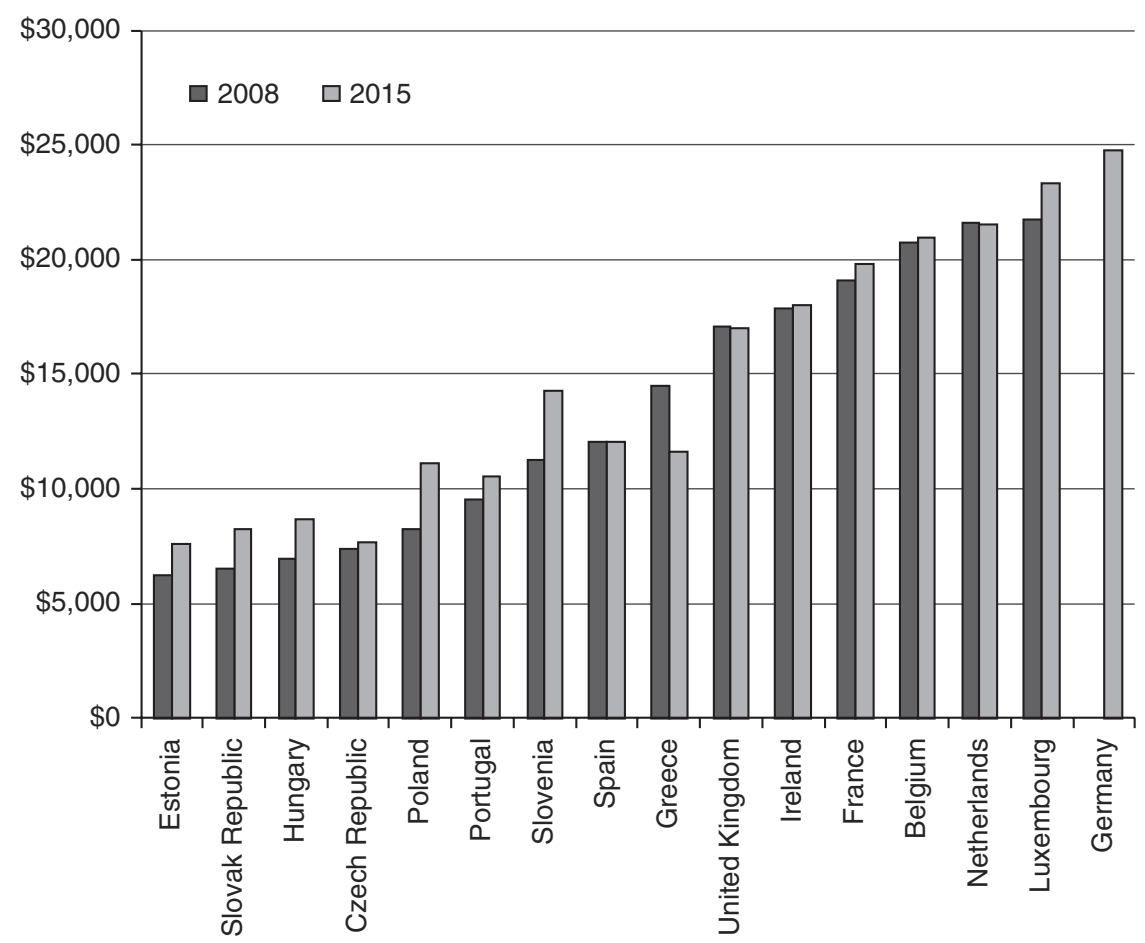

Figure 17.2 Real annual minimum wages, 2008-15, at 2014 prices (US\$ PPP)

Source: OECD statistics online (extracted 21 August 2016).

Ireland, Belgium and the Netherlands) and dropped in one country (Greece, by 20 per cent).

During the period 2008-15, median wages increased less so than minimum wages in all EU countries with a statutory minimum wage, except Ireland where the opposite occurred, and in France, Belgium and Spain the national minimum wage and median wage grew at the same pace. In Greece, the minimum wage reduced more than median wages. As a result of the above trends, the relative minimum wage - as measured by change in the Kaitz index - decreased in Greece and Ireland, remained stable in France, Belgium and Spain, and rose in the other EU countries shown (Figure 17.3). The developments in the relative minimum wage have therefore narrowed earnings inequalities at the bottom end of the wage distribution in countries where the Kaitz index increased since the beginning of the crisis and widened earnings inequalities in the few where it has fallen -namely, Greece and, especially, Ireland.

Overall, the different patterns can be collected into four groups of change 


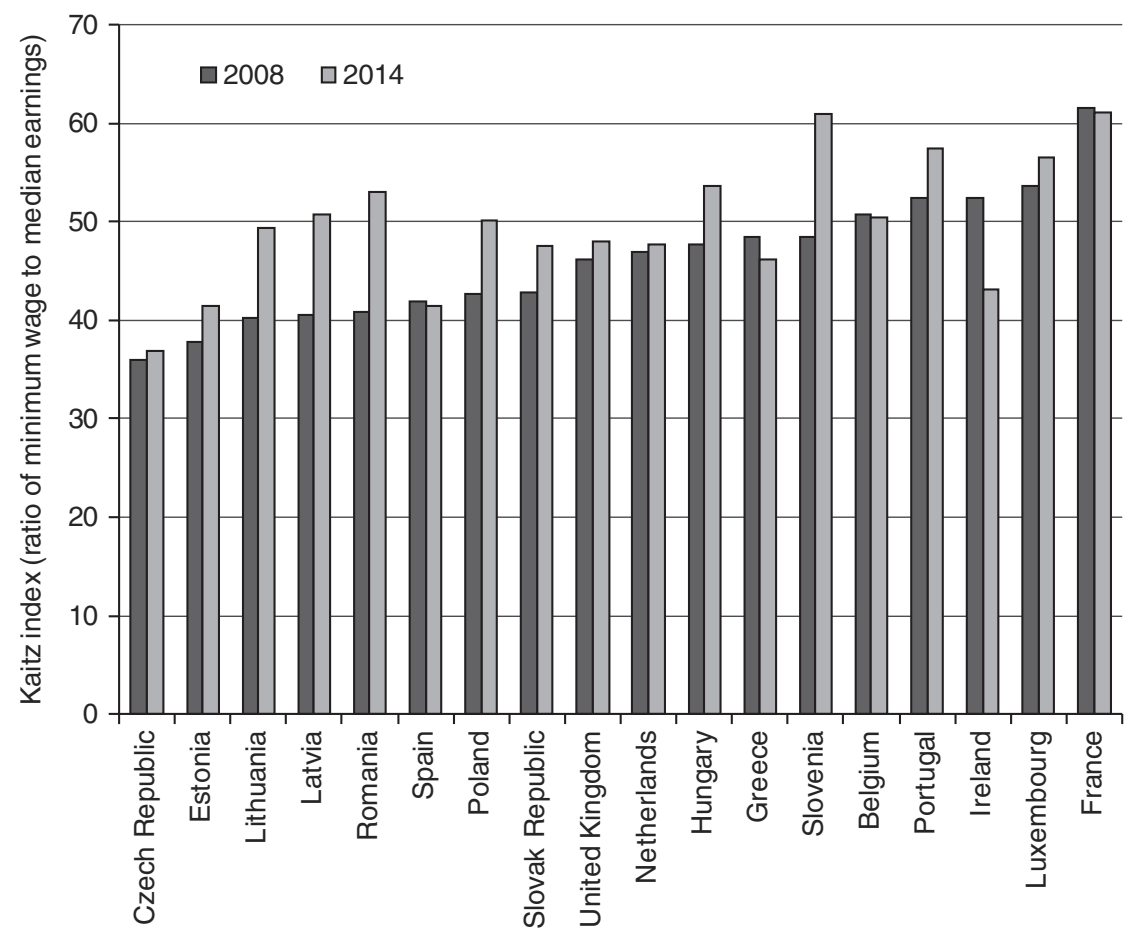

Figure 17.3 Change in the Kaitz index (minimum wage relative to median earnings), 2008-14

Source: OECD statistics online (extracted 21 August 2016).

over the period 2008-15 according to trends in real minimum wages and relative minimum wages (Table 17.1). The largest group of countries - seven of the 15 countries for which we have complete data - have experienced upwards trajectories in both the real and relative values of their minimum wages. A second group of five countries, among them the UK, experienced either limited change (flat trend) in both values or upwards change in one of either real or relative values. A third group experienced a drop in one of the indicators, experienced by Ireland during the period shown. And, finally, Greece occupies the group in which both real and relative values fell significantly during the period.

\section{Explaining state policy towards minimum wage fixing}

Evidence of divergent minimum wage trends reviewed above is further complicated by a likely variety of economic and political thinking that underpins the 
Table 17.1 Patterns of change in real minimum wages and Kaitz index, 2008-14/15

\begin{tabular}{lcccc}
\hline & \multicolumn{3}{c}{ Kaitz index } \\
\cline { 3 - 5 } Real MW & Up & C. --- & Blat & Up \\
Flat & C. Ireland & $\begin{array}{c}\text { B. Belgium, Czech } \\
\text { Rep., France, } \\
\text { Netherlands, Spain } \\
\text { C. --- }\end{array}$ & $\begin{array}{c}\text { A. Estonia, Hungary, } \\
\text { Luxembourg, Poland, } \\
\text { Portugal, Slovakia, Slovenia } \\
\text { B. UK }\end{array}$ \\
\hline
\end{tabular}

Notes: Up is for rises of 5\%+ (Real minimum wage (MW)) or $1.5+$ points (Kaitz) and Down is for falls of more than $-5 \%$ or -1.5 points. The cells are grouped into four categories, A-D; '_- signifies no country examples.

Source: Figures 17.2 and 17.3.

Table 17.2 Five frames for understanding state policy towards wage-fixing

Collective bargaining:

\begin{tabular}{|c|c|c|c|c|}
\hline & & Dismantle & Mostly neutral & Supportive \\
\hline \multirow{3}{*}{ 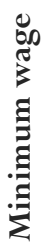 } & Raise & \multirow[t]{2}{*}{$\begin{array}{l}\text { Crowding-out } \\
\text { (Aghion et al., 2011) }\end{array}$} & \multirow[t]{3}{*}{$\begin{array}{l}\text { Legitimation } \\
\text { (O’Connor, 1973) }\end{array}$} & $\begin{array}{l}\text { Participative distribution } \\
\text { (Sen, 1999) }\end{array}$ \\
\hline & Neutral & & & $\begin{array}{l}\text { Collective self-regulation } \\
\text { (Kahn-Freund, 1959) }\end{array}$ \\
\hline & Cut & $\begin{array}{l}\text { Neoliberal shift } \\
\text { (Howells, 2015) }\end{array}$ & & \\
\hline
\end{tabular}

policy approaches. If we consider theoretical rationales for state interventions to raise or cut the minimum wage, then we can identify five possible frames of analysis, each of which considers the intersection with collective bargaining (Table 17.2). It may be, as the writings of Aghion and colleagues (2011) suggest, that states intervene to raise the minimum wage as a direct response to a perceived erosion of trust and cooperation in labour markets (especially between workers and employers). The problem is that there is a strong tendency for a self-perpetuating dynamic such that, on the one hand, the higher minimum wage under stringent state control discourages the formation of trust (by limiting opportunities for workers and employers to build experience at cooperating in wage bargaining) and, on the other, sustained experience of non-cooperation 
generates demand by citizens for stronger state intervention in setting minimum wage standards (Aghion et al., 2008). In other words, the active state-controlled minimum wage policy in this view crowds out collective forms of wage negotiation (for the case of France, see Gautié, 2011). Some states may even seek purposefully to undermine the foundations for collective wage bargaining while simultaneously actively raising the minimum wage; this is in other words a strongly non-participative approach to distribution.

A second frame of analysis is that states are in fact responding to the problem of legitimation as identified in O'Connor's (1973) early study on the fiscal crisis of the state. The idea is that any capitalist state must respond to dual pressures both to foster private capital accumulation and to legitimise (to citizens) the unequal and destabilising effects of accumulation through policies of income redistribution and social protection; it can be interpreted as a struggle between providing for market justice and social justice. As capitalism becomes more and more disorganised in a race to accumulate, then raising the statutory minimum wage may bolster support for (or subdue resistance against) the liberalisation project (Koçer and Visser, 2009). Unlike the crowding out frame, the thesis of legitimation is (in our interpretation) ambivalent about the procedure for raising the minimum wage: it may be achieved through trusting, tripartite forms of social dialogue - deliberative negotiation rather than stringent state control since the distributive result is what matters for legitimation. There is a limit to redistribution of course, since it must not constrain employer profitability in this perspective; similar to flexicurity packages of reforms post-crisis, states pare back protections while sustaining full respect for the imperative of business flexibility (Heyes, 2013). Moreover, it may also be complemented by deregulatory labour market policies that provide employers with 'exit options', by strengthening employer discretion to adjust other employment conditions (Jaehrling and Méhaut, 2013).

We describe a third more positive policy frame as 'participative distribution', inspired by the writings of Sen and the Webbs on the potential for virtuous circles between equality and development. This type of policy action suggests a state finely attuned to the intricacies of a strongly complementary institutional setting, involving tripartite consideration of the conditions for, and effects of, minimum wage rises, a strong and coordinated trade union role in collective bargaining (in low-wage sectors especially), highly engaged employers (e.g. as members of industry associations) and quite possibly a proactive, egalitarian approach to issues of pay equity.

At the other end of the spectrum, 'neoliberal shift' describes the purposeful actions of a nation state (or pan-national authority) designed both to reduce the wage floor and to curtail the reach and effectiveness of collective bargaining 
in a determined effort to shrink labour's share of national income, possibly to depress real wages in an effort to boost competitiveness and also to accelerate labour market deregulation. In Howells' critical analyses $(2015,2016)$ there is a sense that stronger state actions, via a raft of legal regulations, are intended to incrementally disembed markets from society - to undo welfare rights, to shift the balance of public and private governance of economic activity, and in particular to rule out collective interference over employment organisation. The restrictive control of minimum wage policy alongside a dismantling of collective bargaining has the effect of substituting legal regulation for collective regulation. This is in direct opposition to our fifth frame of analysis shown in Table 17.2, that of collective self-regulation, or 'collective laissez-faire' to use Kahn-Freund's description of post-war UK where social partners assume full authority for wage-fixing backed up by state support for participative (that is, collectively negotiated) standards (see also Bosch and Lehndorff, chapter 2, this volume).

In the following analysis, we apply these different policy frames to the cases of Greece and the UK. In particular, we argue that in response to an attack on prevailing institutions (rather than incremental, path dependent change) Greece has experienced a radical change in minimum wage policy approach from one characterized by 'collective self-regulation' to its opposite form, that of 'neoliberal shift'. The UK, by contrast, appears set on a 'crowding out' policy approach, as we explore below.

\section{Greece: minimum wage policy as 'neoliberal shift'}

Greece is currently living through its ninth year of recession during which GDP has fallen by 26 per cent, disposable income by 30 per cent and the average wage by 26 per cent, while unemployment reached more than a quarter of the labour force (27 per cent) and the risk of poverty or social exclusion more than one in three of the population (36 per cent). Since the eruption of the sovereign debt crisis in late 2009, Greek governments have been obliged to implement three Economic Adjustment Programmes (EAP), under the supervision of the Troika and currently the Quartet, ${ }^{2}$ as a prerequisite for the loans granted in 2010, 2012 and 2015 by Eurozone partners and the International Monetary Fund.

Prior to 2012, Greece's minimum wage was determined by national-level collective bargaining and was a core feature of its wage-setting system. In 2012 and 2013, the Greek government introduced radical changes in the determination of the minimum wage as a final step in the complete recasting of the pre-crisis 
wage-setting system. The government first bypassed the national collective bargaining by unilaterally imposing a lower statutory minimum wage (and a new subminimum for workers aged under 25 years old) and then abolished collective bargaining on minimum wages altogether. State intervention in minimum wage policy is only one component of the neoliberal attack on labour rights that has been orchestrated under the first two EAPs adopted in 2010 and 2012 respectively (Karamessini, 2012). The attack had two core goals: (1) to reduce nominal unit labour costs and restore losses in price competitiveness after Greece's entry in EMU; and (2) to recast the wage determination system in order to make wage developments conducive to export-led growth.

\section{Minimum wage policy pre-crisis: 'collective self-regulation'}

Before 2012, the national minimum wage was an integral part of collective bargaining and a key instrument of wage determination in Greece, which was one of three EU countries (with Belgium and Estonia) to set the national minimum wage through bipartite negotiations (Schulten, 2012). National-level bargaining on the minimum wage was a core element of the post-war collective bargaining system established in 1955. The General Confederation of Greek Labour (GSEE) and peak employer organisations regularly signed the National General Collective Agreement (NGCA), which not only determined the minimum wage but also set the floor for various employment conditions and workers' rights. National-level bargaining on sectoral or occupational minima was the second most important feature of the Greek collective bargaining system. Companylevel bargaining was added after 1974 and improved upon sector and occupation minima.

While for most of the post-war period minimum wages were fixed jointly by employers and unions, there were periods of state intervention. In 1982, the government raised the national minimum wage by 48 per cent ( 23 per cent in real terms) with subsequent annual adjustments fixed by inflation-linked indexation. This indexation system was abolished in 1990. At the same time, a new law on 'free' collective bargaining replaced compulsory state-controlled arbitration, effective since 1955, with independent third-party mediation and arbitration.

The Greek wage-setting system of the 1990s and 2000s combined bipartite negotiation of a national minimum wage with relatively high collective bargaining coverage (65 per cent in 2009). The latter was achieved through both the regular use of extension mechanisms by the Minister of Labour and a system of articulated, multi-layered and coordinated collective bargaining. As in Spain during the 1990s and much of the 2000s, the national minimum wage operated in 'distant coexistence' with the basic wage rates negotiated in collective 
agreements (Grimshaw and Bosch, 2013: 59) such that its coverage in the official labour market was very low: less than 1 per cent of employees in firms with 10 or more employees were paid up to 105 per cent of the minimum wage in 2010 (OECD, 2015: figure 1.13) and this rate would remain low even if employees from small firms were included. However, national bargaining on the national minimum wage was extremely important in two respects. First and foremost, minimum wage increases functioned as a minimum standard for national sector and occupation-level bargaining. Depending on their bargaining power and the particular conditions in their industry or occupation, unions customarily set their target increases somewhere between minimum wage increases and those achieved by the most powerful public utilities and banking federations. This customary union bargaining behaviour explains the uninterrupted fall of the Kaitz index from the early 1980s right up to the crisis years (Figure 17.4). In the late 1990s, the bargaining rounds between management and the strong unions in public utilities and banking were decoupled from the bipartite fixing of the national minimum wage. A basic mechanism of articulated bargaining and wage drift was thus broken (Ioannou 2000). However, public utilities and banking remained in the 2000s - as in the 1980s and the 1990s - the strongholds of the

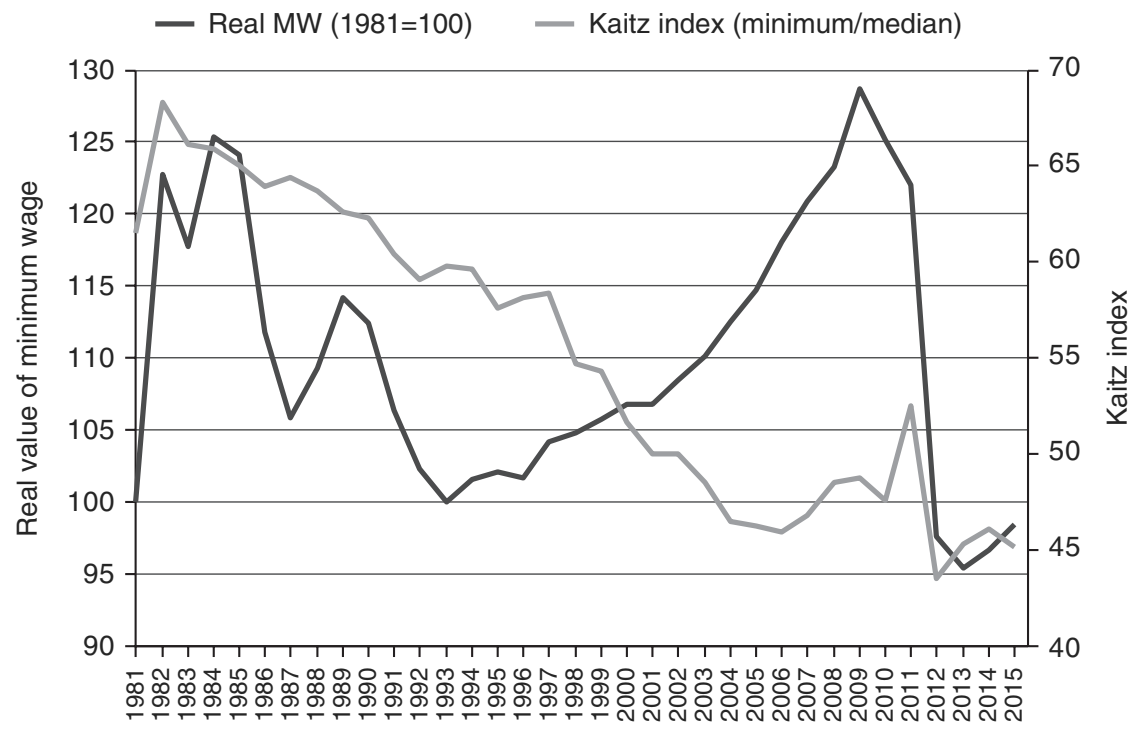

Figure 17.4 Trends in the real minimum wage and Kaitz index in Greece, 1981-2015

Notes: MW refers to minimum wage.

Source: OECD statistics online (extracted 21 August 2016). 
union movement and dominated the leadership of GSEE. General strikes supported by these unions were often used to reinforce GSEE's bargaining power during negotiations on the minimum wage. A second reason for the importance of the national minimum wage during the 1990s and 2000s was that it constituted a reference point for individual bargaining on pay in the relatively large informal labour market, similar to evidence in other countries of the "lighthouse effect' of minimum wages (Boeri et al., 2010).

Alongside constant and robust productivity growth, the above-described wage-setting system allowed for an uninterrupted increase in both the real minimum wage (Figure 17.4) and the real compensation per employee in the period 1993-2009 equal to 29 per cent and 53 per cent, respectively (in cumulative terms). The multi-layered and coordinated system of collective bargaining led to important wage inequalities, especially between the public and private sectors, but at the same time reinforced the middle of the wage distribution through national bargaining on sector and occupational minima and established relatively low inequality in the bottom half of the wage distribution; the pre-crisis Kaitz level was still higher than the EU average in 2008 (Figure 17.3). As for the real value of the minimum wage (purchasing power), this was also above the EU average at that time (Figure 17.2).

\section{Minimum wage policy, internal devaluation and deregulation of the wage- setting system}

Reducing labour costs in the business sector of the economy was one of the key goals of the first EAP (2010-11) that considered it central to the process of internal devaluation intended to boost price competitiveness and reduce the external deficit. This goal became an explicit and quantified target under the second EAP (2012-15), which necessitated a 15 per cent reduction. To achieve it, the first EAP imposed measures designed to decentralise collective bargaining (Dedoussopoulos et al., 2013; Ioannou, 2012; Karamessini, 2012, 2015; Koukiadaki and Kokkinou, 2015), including suspending the extension of collective agreements by the Minister of Labour to non-signatory firms, ensuring that firm-level agreements prevail over sector and occupational agreements by abolishing the 'favourability' clause and allowing 'associations of persons' (nonunion organisations usually set up by employers) to sign firm-level collective agreements instead of unions.

Despite the reforms, the pace of wage reductions during 2010 and 2011 was deemed too slow. The Troika and the Greek government pinned the blame on continued rises in the national minimum wage (equal to inflation for the Eurozone region), which had been agreed by the NGCA in July 2010. In their 
view, such rises conflicted with the goal of labour cost reduction (Kanellopoulos, 2015). The government launched a tripartite dialogue to discuss national minimum wage developments compatible with boosting competitiveness and preserving employment. But the Troika considered the results of this dialogue unsatisfactory since they did not ensure 'the quick responsiveness of wages to the fall in economic activity' (European Commission, 2012: 38). Koukiadaki and Kokkinou summarised the views of the social partners as follows:

'During the discussions, the employers' associations opposed the reduction of the minimum wage but were in favour of a three-year freeze in wage and maturity increases and the reduction in social insurance contributions. On the other hand, the GSEE [unions] rejected any change in relation to wage costs and stated that the discussion should focus only on non-wage costs.' (2015: 145)

The stalemate led the Troika and the government to design, in 2012, a series of measures building on two pillars: an immediate and drastic reduction of wage floors and the completion of the 2010-11 reforms to radically recast the wagesetting system. The 2012 measures can be grouped as follows:

- Legislative reduction of the minimum wage by 22 per cent followed by a freeze until the end of 2016.

- Introduction of a lower minimum wage for young people under the age of 25 years, at 87 per cent of the reduced minimum wage followed by a freeze until the end of 2016.

- Further dismantling of the collective bargaining system through the reduction to three months of the after-effects of collective agreements and freedom to negotiate individual contracts thereafter; the elimination of unilateral recourse to arbitration and its restriction to ruling only the basic wage; the freeze of all seniority bonuses provided by law or collective agreements; and the removal of 'tenure' from all existing labour contracts.

- Invitation to social partners to simplify the NGCA by establishing a singlerate statutory minimum wage and to abolish the multiple minimum wages according to type of work, education, marital status and seniority. The subsequent failure of the National Committee for Social Dialogue, set up in September 2012, to agree a reform led to a government-imposed (following consultation) national minimum wage from January 2017, which is said to be fully compatible with a decentralised and individualised system of industrial relations.

These decisions were taken with the goal of encouraging sizeable reductions in nominal wages across the whole economy and thereby generate the 15 per cent 
Table 17.3 Wage developments, Greece 2008-15

\begin{tabular}{lcc}
\hline & \multicolumn{2}{c}{ Annual rates (\%), nominal } \\
\cline { 2 - 3 } & Minimum wage & Average wage* \\
\hline 2008 & 3.4 & 3.7 \\
2009 & 5.8 & 3.1 \\
2010 & 2.7 & -2.0 \\
2011 & 6.8 & -3.8 \\
2012 & -21.4 & -3.0 \\
2013 & 0.0 & -7.0 \\
2014 & 0.0 & -2.1 \\
2015 & 0.0 & -1.7 \\
\hline
\end{tabular}

Notes: * Nominal compensation per employee; total economy.

Source: Authors' calculations from Eurostat online minimum wage database; European Economy, Statistical Annex, Spring 2016 for average wage.

contraction of labour costs specified in the second EAP as needed to reverse losses in labour cost competitiveness of domestic production during 2000-09. Having increased by 10 per cent between 2008 and 2011, the nominal minimum wage fell abruptly by 22 per cent in 2012 and remains at the same nominal level at the time of writing (mid-2016). Adjusted for prices, the real value of the minimum wage fell by 24 per cent between 2010 and 2015, bringing to an end a long period since the mid-1990s of steady real gains in the wage floor for the Greek workforce (Figure 17.4). Average nominal earnings data show annual declines of between 2 and 7 per cent during 2010-15 (Table 17.3), resulting in a cumulative loss of 18 per cent.

As well as forcing through major cuts in nominal wages across the whole wage distribution, the reduced minimum wage and the new subminimum for youth (with the notoriously high 'adult' age of 25 years old) were also explicitly intended by the authors of the second EAP (European Commission, 2012: 38 ) to (1) send a strong signal to employers and unions bargaining wages in other sector- and firm-level agreements (2) reduce informality and undeclared work by pulling the latter into the formal labour market; and (3) widen differentials at the bottom end of the wage distribution, thought to price out of employment the low-skilled who might receive payments at or above the minimum wage. In fact, because average earnings have been in continuous freefall since 2010 (owing to the depressed macroeconomic climate and the dismantled collective bargaining system), the bottom half of the wage distribution has become more compressed following the one-off minimum wage cut in 2012. 
Table 17.4 Wage inequality indicators, Greece 2004-14

\begin{tabular}{lccccccc}
\hline & $\mathbf{2 0 0 4}$ & $\mathbf{2 0 0 7}$ & $\mathbf{2 0 0 9}$ & $\mathbf{2 0 1 1}$ & $\mathbf{2 0 1 2}$ & $\mathbf{2 0 1 3}$ & $\mathbf{2 0 1 4}$ \\
\hline Kaitz index & 46.5 & 46.8 & 48.7 & 52.5 & 43.5 & 45.3 & 46.1 \\
Low pay incidence & 20.0 & 15.1 & 15.1 & 12.3 & 11.8 & 13.9 & 17.9 \\
\hline
\end{tabular}

Notes: The incidence of low-paid workers is defined as the share of full-time workers earning less than two-thirds of gross median earnings of all full-time workers.

Source: OECD statistics online (data extracted on 21 August 2016).

We can identify four successive periods (Tables 17.3 and 17.4): (1) 2007-09the Kaitz index increased as a rising minimum wage outpaced average wages; (2) 2009-11 - the Kaitz index again increased but this time owing to steady growth in the minimum wage alongside falling average earnings; (3) 2012 - the one-off cut in the minimum wage produced an unprecedented nine-point drop in the Kaitz index; and (4) 2012-14 - as the nominal value of the minimum wage was frozen in 2012 and average wages have declined each year since, the Kaitz index increased, which is absolutely contrary to the desired goals of the second EAP.

During this period, the deregulation of the wage-setting system has led to the individualisation of wage bargaining and, ultimately, under conditions of mass unemployment, to a compression of wage differentials towards the minima. It is noteworthy that the number of sector and occupational collective agreements and arbitration awards has fallen from 101 in 2009 to 23 in 2015, while the coverage of employees by collective agreements fell from 65 per cent in 2009 to 40 per cent in 2013 (ILO, 2015b); forthcoming data will undoubtedly reveal an even lower rate. Moreover, the institutional deregulation identified with the 'neoliberal shift' in Greece has caused not only huge wage devaluation, but also a rising share of low-paid workers since 2011 (Table 17.4) even when we use an indicator that refers to a depressed median wage.

Under the third EAP (2015-18) a commission of high-level international experts was formed in March 2016 to make independent recommendations and other reforms in industrial relations. The commission has not concluded with a unified proposal. Nevertheless, a majority of its members have recommended a return to bipartite negotiations of the national minimum wage with automatic erga omnes effects, but only after consultation with an independent group of experts, and the replacement of the special minimum wage for youth by experience-based subminimum wages for a maximum of two years (Hellenic Republic, Ministry of Labour, Social Security and Social Solidarity 2016: 2-3). 


\section{The UK: a case of 'crowding out'?}

The UK is quite different: the government intervened in 2016 to raise the minimum wage over a medium-term period in order both to arrest the stagnant trend in real earnings growth and to reduce public expenditures on in-work benefits claimed by many millions of low-wage workers. At the same time, however, the UK policy approach shares similarities with Greece in the policy interactions with participative forms of wage-fixing, albeit displaying a passive disconnect with collective bargaining rather than an outright 'frontal assault', as Marginson (2014) puts it for Greece. We explore these issues here.

Prior to its introduction of a national statutory minimum wage in 1999, the UK had, for several decades, applied a complex system of minimum wage protection that was jointly regulated by unions and employers without state intervention. These 'Wages Councils' (founded in 1909 as 'Wages Boards') operated in 66 sectors at their peak, covered around 3.5 million workers and fixed overtime and holiday entitlements as well as wage rates (Burgess, 2006). The government abolished them in 1993 as part of a wider deregulatory labour market policy approach. ${ }^{3}$ The problem, however, was that it left a considerable hole in wage protection, since the 1980s had witnessed a significant drop in collective bargaining coverage; the near-comprehensive collective bargaining structures of the period 1950-80 had quickly collapsed to a minority of the private sector workforce already by the early 1990s (Brown, 2010: figure 11.1). As such, the early-twentieth-century rationale for the introduction of Wages Councils - namely, that many workers were employed in sectors without collective representation and deserved protection from wage exploitation - was once again true and paved the way for unions' newfound positive support, leading eventually to a government determination to establish (under the Labour party) a national statutory minimum wage (effective from 1999).

Nevertheless, while the policy approach was inclusive of employers and unions in the process of minimum wage-fixing - via the reputable, independent Low Pay Commission (see Brown, 2009) - it was not accompanied by policies designed to prop up collective bargaining or to establish stronger 'participative standards' in the UK labour market. ${ }^{4}$ Collective bargaining coverage continued to decline during the 2000s (down to an estimated 16 per cent in the private sector by 2015). From the outset, therefore, the minimum wage policy approach generated a clear risk that wages would cluster around a single regulated wage rule at the very bottom of the wage distribution (Grimshaw, 2010). Figure 17.5 displays the characteristics of the UK's 'isolated' minimum wage policy visually, showing the falling private sector collective bargaining coverage (from an 


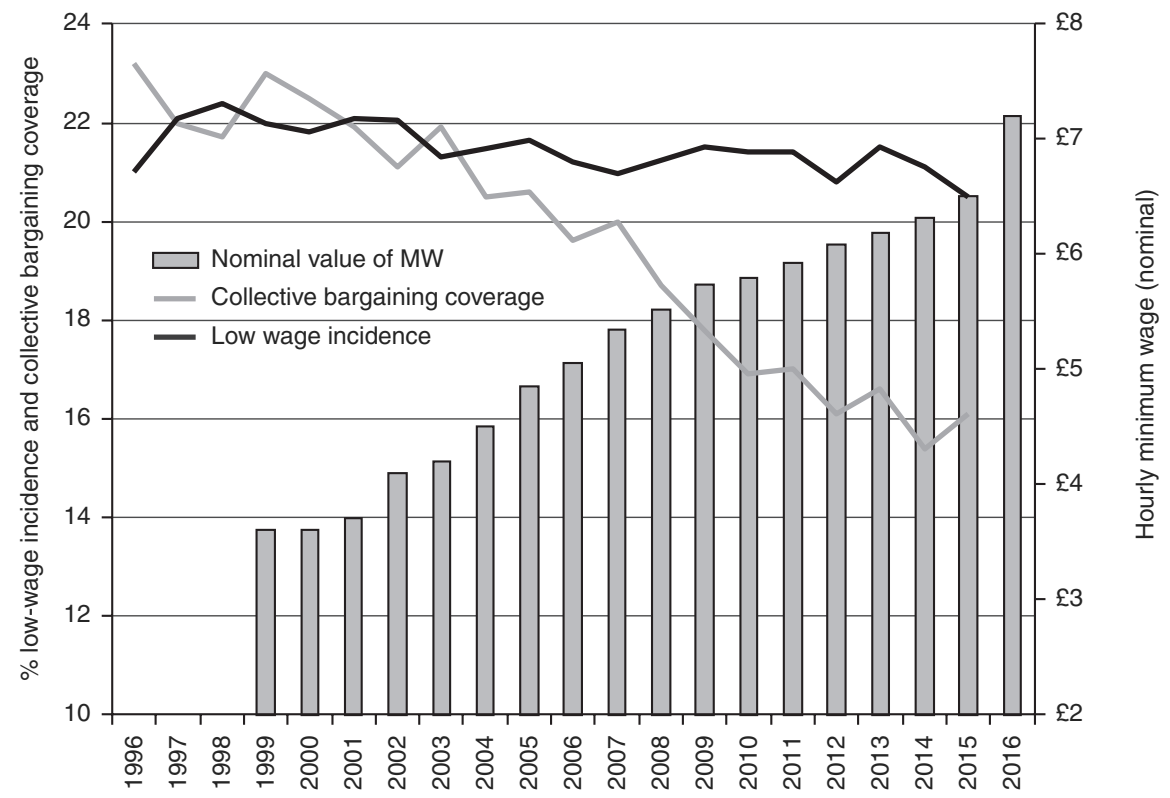

Figure 17.5 Trends in the minimum wage, collective bargaining coverage (private sector) and the incidence of low pay in the UK, 1996-2016

Notes: Low-wage incidence defined as share of employees earning less than two-thirds median gross hourly earnings; MW refers to minimum wage.

Source: Annual Survey of Hours and Earnings for low-wage incidence (authors' estimates from published data); private sector collective bargaining data from BIS (2016: table 2.4b).

already very low level), the steady rise (except the crisis years) in the minimum wage and the persistent high share of the low-wage workforce, averaging around 21-22 per cent throughout the 20-year period shown.

Compared to the situation in Greece (see Figure 17.4), the pre-crisis decade of real minimum wage gains in the UK looks similar in terms of the positive upwards trend, although the UK delivered higher real gains overall: OECD data show that for 2000-09 the real minimum wage recorded a 33 per cent rise in the UK (Figure 17.6) compared to 21 per cent in Greece. Thereafter, of course, the two country narratives are completely divorced. While the UK slowed down minimum wage rises during the crisis, which translated into a cumulative 5 per cent real cut from peak to trough (2009-13), the minimum wage in Greece went into a tailspin following the Troika's instructions, amounting to a 26 per cent real cut in the same period (OECD data). Trends in each country's relative minimum wage value also differ, with a notably steady upwards trend 


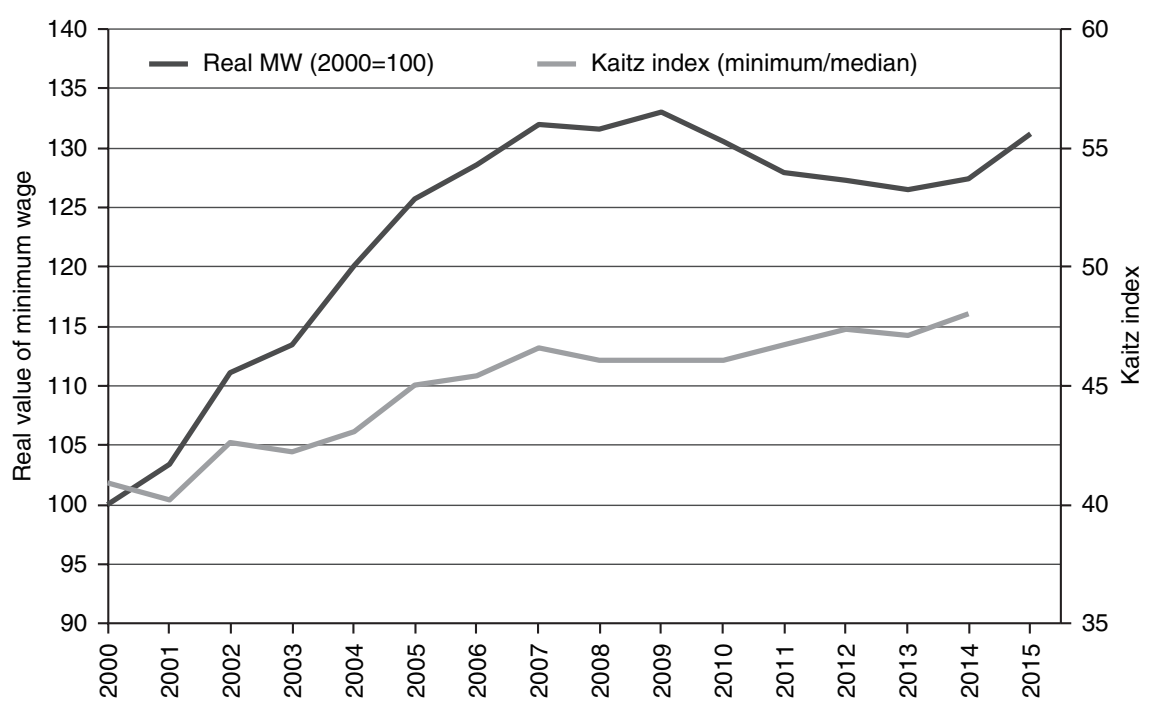

Figure 17.6 Trends in the real minimum wage and Kaitz index in the UK, 2000-15

Note: MW refers to minimum wage.

Source: OECD statistics online (extracted 6 October 2016).

in the UK (from 41 per cent to 48 per cent of median earnings) and a fluctuating trend in Greece punctuated by the steep drop in 2012 (from 53 per cent to 44 per cent of median earnings). What seems clear for the UK, therefore, is that low-wage workers have benefited from a relatively reliable statutory minimum wage instrument. It delivered large-scale gains during the good economic times, did not over-react during the crisis (although Greece is not necessarily a fair comparator) and has gradually shifted the position of the wage floor upwards relative to the wage distribution's mid-point; 2014 data place the UK just below the OECD 18-country average - Kaitz measures of 48 per cent and 50 per cent respectively (see Figure 17.3 above).

Nevertheless, the persistently high share of low-wage employment suggests all is not well in the UK's labour market. If the wage floor is rising against median earnings and the share of workers earning between the minimum wage and a threshold of two-thirds of median earnings is high and stable, it would appear that the rising minimum wage is not generating a sufficiently strong ripple effect in the bottom half of the wage structure. Instead, it seems that in the UK's weak and perforated industrial relations context - absent of other wage standards set for example by industry collectively bargained rates - the statutory minimum wage acts as a dominant 'external key rate' for many employers and proves far more important than productivity or human capital 
factors in wage-setting. Bryson and Lucchino (2014), for example, find almost one in three UK workplaces mention the minimum wage as an influence on their largest occupational group. The result is that very strong 'wage contours' around the minimum wage are generated in many segments of the labour market (after Dunlop, 1957). We would expect the UK to mirror to a large extent the situation in the USA. There, research finds evidence of minimum wage contours in several sectors, suggesting wage structures for many occupational groups are more closely tied to minimum wage trends than other factors such as changing skills and work experience (Levin-Waldman, 2002; Rodgers et al., 2004).

We interrogate the UK data here by examining what has been happening with levels of pay just above the minimum wage for male and female workers namely, at earnings up to 10 per cent, 20 per cent and 30 per cent higher than the minimum wage. Table 17.5 presents earnings data for these three 'wage contours' for the period 1999-2012. Three findings are significant.

1) The 2003-12 period of a rising minimum wage (nominal and Kaitz, see above) was consistent with a growing concentration of both men and women in all three low-wage contours shown. This strongly supports the thesis that the minimum wage became an increasingly dominant 'external key rate' during the period. It also points to weak wage spillover effects (see also Dickens and Manning, 2015; Stewart, 2012). ${ }^{5}$

2) The three observed minimum wage contours are far more strongly embedded for women than for men; in 2012, 15 per cent of women and 8 per cent of men (adults) were paid in the first wage contour of very low wages (minimum wage plus 10 per cent, equivalent to a gross hourly wage of $£ 6.08-£ 6.69$ at the time); and at the second wage contour (minimum wage plus 20 per cent) we find almost a quarter of all women employed (23 per cent) and one in seven (14 per cent) men.

3) There has been a diminishing of the gender divide since 2003. For example, while in 2003 women faced almost three times the likelihood as men of being paid in the second wage contour, by 2012 this had reduced to less than twice the risk. However, the risk for both groups increased significantly and by a similar size in terms of numbers affected: both witnessed a rise of approximately 1 million (1.01 million male workers and 0.98 million female workers) paid in the second wage contour (minimum wage plus 20 per cent) over this nine-year period. ${ }^{6}$

Furthermore, the increasing segmentation of low-wage workers in minimum wage contours during the pre- and post-crisis periods have exerted a significant 
Table 17.5 Minimum wage contour trends in the UK: the share of female and male employees in pay bands above the minimum wage, 1999-2012

\begin{tabular}{|c|c|c|c|c|}
\hline & 1999 & 2003 & 2008 & 2012 \\
\hline \multicolumn{5}{|l|}{$\begin{array}{l}\text { First wage contour } \\
(\mathrm{MW}+10 \%)\end{array}$} \\
\hline Women & $11.9 \%$ & $9.5 \%$ & $12.7 \%$ & $15.0 \%$ \\
\hline Men & $4.1 \%$ & $3.2 \%$ & $5.7 \%$ & $8.4 \%$ \\
\hline \multicolumn{5}{|l|}{$\begin{array}{l}\text { Second wage contour } \\
(M W+20 \%)\end{array}$} \\
\hline Women & $20.7 \%$ & $16.7 \%$ & $20.4 \%$ & $23.2 \%$ \\
\hline Men & $7.6 \%$ & $6.0 \%$ & $9.7 \%$ & $13.6 \%$ \\
\hline \multicolumn{5}{|l|}{$\begin{array}{l}\text { Third wage contour } \\
(M W+30 \%)\end{array}$} \\
\hline Women & $27.7 \%$ & $24.9 \%$ & $26.4 \%$ & $30.1 \%$ \\
\hline Men & $11.3 \%$ & $10.0 \%$ & $13.2 \%$ & $18.4 \%$ \\
\hline $\begin{array}{l}\text { Minimum wage as } \% \\
\text { of median pay }\end{array}$ & $47.6 \%$ & $47.5 \%$ & $52.4 \%$ & $54.2 \%$ \\
\hline $\begin{array}{l}\text { Median pay as } \% \\
\text { of minimum wage }\end{array}$ & $\mathrm{MW}+110 \%$ & $\mathrm{MW}+111 \%$ & $\mathrm{MW}+91 \%$ & $\mathrm{MW}+84 \%$ \\
\hline $\begin{array}{l}\% \text { women paid below } \\
\text { median pay }\end{array}$ & $61 \%$ & $60 \%$ & $58 \%$ & $57 \%$ \\
\hline $\begin{array}{l}\% \text { men paid below } \\
\text { median pay }\end{array}$ & $39 \%$ & $40 \%$ & $42 \%$ & $43 \%$ \\
\hline
\end{tabular}

Notes: MW refers to minimum wage; the minimum wage level in April for each year was $£ 3.60$ (1999), £4.20 (2003), £5.52 (2008) and $£ 6.08$ (2012); data referring to the three tiers refer to adults aged $22+(1999-2008)$ and $21+(2012)$; median pay refers to all employees on adult rates (male, female, full-time, part-time) and was $£ 7.57$ (1999), £8.85 (2003), £10.54 (2008) and £11.21 (2012) (gross hourly, overtime excluded, nominal.

Source: ASHE earnings data (ons.gov.uk), 'Distribution of low paid jobs by 10p bands' and 'Annual Survey of Hours and Earnings: Table 1 All employees'; authors' original compilation.

downwards drag on median earnings. Adjusting for prices (using the Retail Price Index), real wages for the UK workforce came to a standstill in the period 2003-08, rose during the crisis year of deflation in 2009 and then went into freefall (dropping 10 per cent) until 2015 when they picked up a little. While other factors were certainly in play, it is notable that GDP per capita increased substantially in 2003-08 and, after a fall in 2008-09, resumed at a fairly steady rise thereafter (Grimshaw and Rafferty, 2016: figure 11). As such, we need to look at factors other than long-standing problems of slow productivity growth, weak capital investment and poor innovation performance that are features of 
the UK's private sector. Our suspicion is that the near-absence of other regulatory arrangements for wage-setting, especially collective bargaining, denies workers and employers an important 'beneficial constraint' (Streeck, 1997). If workers had more 'voice' in negotiating and defending wages (as in France and Germany, for example) then this would allow them to leverage minimum wage gains further up the wage distribution (Grimshaw et al., 2014). Instead many low-wage employers appear to be responding by fusing job grades at lower levels, collapsing customary wage differentials between supervisory and nonsupervisory grades and using the minimum wage as a standard rate rather than as a floor against exploitation.

As well as acting as a drag on median earnings, a high share of workers in low-wage jobs imposes a significant cost on the welfare state in the form of in-work benefits ('tax credits' in the UK). Partly in response to this issue, the government introduced a new higher adult minimum wage (for workers aged 25 plus as in Greece) fixed initially in 2016 at approximately 7 per cent higher than the rate for 21-24 year olds. More radically, the government said it would require the Low Pay Commission to raise the new premium adult rate to $£ 9.00$ (from the $2016 £ 7.20$ rate) or 60 per cent of median earnings by $2020 .^{7}$ This intervention is significant for two reasons. Firstly, for the first time since the establishment of the tripartite Low Pay Commission in 1999, the government has asserted control over the fixing process, thereby strengthening government power and diminishing the voice of employer and trade union organisations. Secondly, it sets what appears to be a very ambitious target for the wage floor, which ought to contribute to reducing the share of workers in low-wage employment.

As estimations in Figure 17.7 show, the two targets generate very different results: the $£ 9$ target would take the minimum wage above the low-wage threshold by 2018, while the 60 per cent target would set in train a slower set of annual rises converging with where the previous minimum wage would have been by 2020. However, it is understood that the $£ 9$ target has been quietly shelved and that when the Low Pay Commission makes its report in October 2016 it will recommend a 2017 rate in line with the 60 per cent target. ${ }^{8}$ As such, it will continue the past trajectory of minimum wage rises with a slow closing of the gap between the wage floor and the low-wage threshold. Nevertheless, without complementary policy reforms to strengthen participative standards, the high share of workers paid in narrow wage contours above the minimum wage is unlikely to change. 


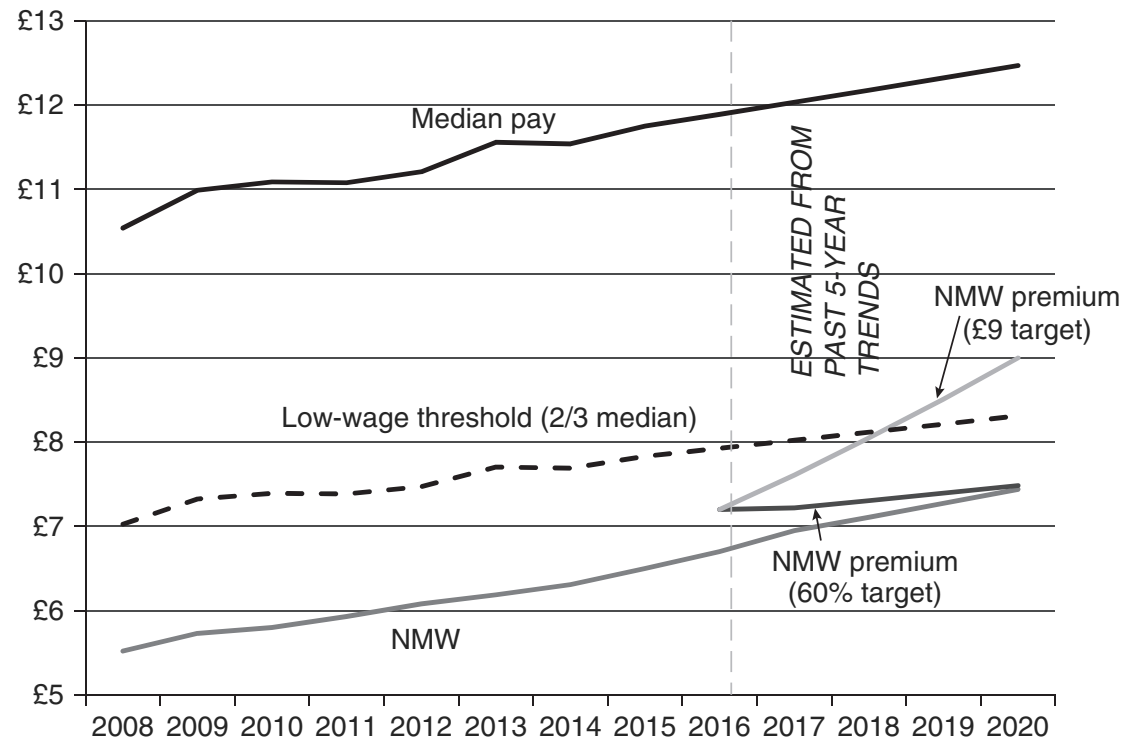

Figure 17.7 Projected minimum wage trends with alternative 2020 targets (nominal value)

Notes: Median pay is for all employees, gross hourly pay excluding overtime, nominal value; NMW is the national minimum wage (adult rate) for April each year; projected median pay for 2016-20 applies the annual average rise recorded for 2010-15 (1.2\%) and the projected NMW trends assume steady rises in rates during 2017-20.

Source: Annual Survey of Hours and Earnings.

\section{Conclusions}

While in 2012 the Greek government cut the minimum wage by 22 per cent as a main plank of its wage devaluation policy approach in a context of relentless economic recession, the UK minimum wage enjoyed small but steady rises during employment recovery, followed by a potentially radical statutory intervention that promises to deliver a succession of minimum wage rises during the period 2016-20 in an effort to cut welfare benefits paid to poor workers. Our two-country analysis has revealed diverging effects on labour costs and the shape of the wage distribution. In Greece, the real value of the minimum wage today is below its level recorded in 1981, according to the OECD's purchasing parity measure; this is an extraordinary indictment of the country's economic management since the 2008 crisis under Troika control. The share of low-wage employment has increased, but this is secondary in significance to the plummeting real 
value of earnings for all workers. The UK's pay problems are different. Here we find a rising wage floor and a flat trend in real median earnings, coupled with a persistent high share of low-wage employment and a growing concentration of workers, especially high among women, paid within 'wage contours' just above the minimum wage.

A key failing in both countries' minimum wage policy approaches is their isolation from potentially complementary wage-setting institutions, namely collective bargaining. The Troika-led interventions in Greece were designed to dismantle long-standing processes of bipartite negotiation in minimum wagesetting by substituting unilateral state action for social partner regulation. We characterised this policy approach as a 'neoliberal shift'. The policy goal was to establish low-level coverage of collective bargaining and individualised industrial relations and to fix the minimum wage as a safety net via a frontal assault against collective bargaining and labour rights at large. It should be stressed, though, that the Tsipras government managed to place the revival of collective bargaining as a core plank of industrial relations reforms under the third EAP. As a result, it has been recently agreed between the government and the Quartet that both the favourability clause in collective agreements and the extension mechanism will be restored in September 2018. In the UK, the radical 2016 policy reform diminished the remit of the tripartite Low Pay Commission by unilaterally fixing the 2020 adult rate so that scope for interaction with social partners in fixing the minimum wage is reduced. The weak presence of collective bargaining in the UK's private sector workplaces means the role of social partners in the minimum wage-fixing process had been important. As such, this statutory intervention acts to 'crowd out' participative decision-making over wages. Both countries therefore have witnessed ruptures to pre-existing intersections with the national industrial relations model, although this is of a far greater scale in Greece and as the result of far more explicit concerted actions. The contrasting cases support the need for better policy approaches that engage with collective bargaining and participative minimum wage fixing processes since these facilitate a more robust approach to sustaining real wage gains and a pay equity approach that supports a wider approach of making work more equal.

\section{Notes}

1 The so-called Troika comprises the European Central Bank (ECB), the European Commission (EC) and the International Monetary Fund (IMF).

2 Namely, the EC, ECB, IMF and the European Stability Mechanism (ESM). 
3 With the exception of the Wages Council for agriculture, which was abolished some years later in 2013 (again by a Conservative government).

4 See Chapter 2 in this volume for a full elaboration of the notion of 'participative standards'.

5 While the studies by Stewart (all sectors) and by Dickens and Manning (elderly care sector) find no evidence of wage spillovers from minimum wage rises in the UK, Butcher and colleagues (2012) find spillovers up to the 25 th wage percentile. The difference is explained by the different time periods examined and the different counterfactual wage distributions used in models (McKnight et al., 2016).

6 During the period 2003-12, the total male workforce increased from 11.44 million to 12.46 million and the total female workforce from 11.14 million to 12.25 million (as recorded in the ASHE earnings database).

7 In its revised remit for the Low Pay Commission, the government states: 'The Government estimates that the level of the combined national minimum wage and the premium in April 2016 will be 55 per cent of median earnings and has set out an ambition that this should continue to increase to reach 60 per cent of median earnings by 2020, subject to sustained economic growth. The Government's objective is to have a National Living Wage of over £9 by 2020’ (BIS, 2015: 2).

8 The 60 per cent target is likely to be estimated against median earnings for workers aged 25 and over, which raises the median slightly and therefore raises the eventual minimum wage by 2020 compared to the line plotted in Figure 17.7.

\section{References}

Aghion, P., Algan, Y. and Cahuc, P. (2008), Can Policy Interact with Culture? Minimum Wage and the Quality of Labor Relations, National Bureau of Economic Research (NBER) Working Paper, w14327.

Aghion, P., Algan, Y. and Cahuc, P. (2011), 'Civil society and the state: the interplay between cooperation and minimum wage regulations', Journal of the European Economic Association, 9:1, 3-42.

Baccaro, L. and Howell, C. (2011), 'A common neoliberal trajectory: the transformation of industrial relations in advanced capitalism', Politics and Society, 39:4, 521-63.

BIS (Business, Innovation and Skills) (2015), National Minimum Wage: Low Pay Commission 2016 (London: Department for Business, Innovation and Skills).

BIS (Business, Innovation and Skills) (2016), Trade Union Membership 2015: Statistical Bulletin (London: Department for Business, Innovation and Skills).

Boeri T., Garibaldi P. and Ribeiro M. (2010), Behind the Lighthouse Effect, IZA (Institute of Labour Economics) Discussion Paper No. 4890 April 2010 (Bonn: Institute of Labour Economics).

Bryson, A. and Lucchino, P. (2014), The Influence of the National Minimum Wage on Pay Settlements in Britain, Report for the Low Pay Commission, London.

Butcher, T., Dickens, R. and Manning, A. (2012), Minimum Wages and Wage Inequality: Some 
Theory and an Application to the UK, CEP Discussion Paper 1177 (London: London School of Economics).

Dedoussopoulos A. with V. Aranitou, F. Koutentakis, M. Maroupoulou (2013), Assessing the Impact of the Memoranda on Greek Labour Market and Labour Relations, Working Paper No. 53, Governance and Tripartism Department (Geneva: International Labour Office) http: / / www.ilo.org/ifpdial/information-resources/publications/WCMS_232796/lang--en/ index.htm, accessed 6 September 2016.

Dickens, R. and Manning, A. (2015), 'Spikes and spill-overs: the impact of the national minimum wage on the wage distribution in a low-wage sector', The Economic Journal, 114:494 (2004) C95-C101.

Eurofound (2016), Statutory Minimum Wages in the EU 2016, European Observatory of Working Life, http://www.eurofound.europa.eu/observatories/eurwork/articles/ working-conditions-industrial-relations/statutory-minimum-wages-in-the-eu-2016

European Commission (2012), The Second Economic Adjustment Programme for Greece, European Economy Occasional Papers No. 94 (Brussels: Directorate-General for Economic and Financial Affairs Publications) ec.europa.eu/economy_finance/publications/occasional_ paper/2012/ pdf/ocp94_en.pdf.

Garnero A., Kampelmann, S. and Rycx, F. (2015), 'Minimum wage systems and earnings inequalities: does institutional diversity matter?', European Journal of Industrial Relations, $21: 2,115-30$.

Grimshaw, D. (2010), 'The UK: Developing a progressive minimum wage in a liberal market economy', in D. Vaughan-Whitehead (ed.), The Minimum Wage Revisited in the Enlarged EU (Cheltenham: Edward Elgar and Geneva: International Labour Organisation).

Grimshaw D., Bosch, G. and Rubery, J. (2014), 'Minimum wages and collective bargaining: what types of pay bargaining can foster positive pay equity outcomes?', British Journal of Industrial Relations, 52:3, 470-98.

Grimshaw D. and Rubery, J. (2013), 'The distributive functions of a minimum wage: firstand second-order pay equity effects', in Grimshaw, D. (ed.), Minimum Wages, Pay Equity and Comparative Industrial Relations (London: Routledge), pp. 81-111.

Hellenic Republic (2016), Ministry of Labour, Social Security and Social Solidarity, Extract from the recommendations of the Commission of Independent Experts, as summarised by its President, Prof. Jan van Ours, Press Release, Athens, www.ypakp.gr/uploads/docs/9946.pdf, accessed 30 September 2016.

Hermann, C. (2014), 'Structural adjustment and neoliberal convergence in labour markets and welfare: the impact of the crisis and austerity measures on European Economic and Social Models', Competition \& Change, 18:2, 111-30.

Heyes, J. (2013), 'Flexicurity in crisis: European labour market policies in a time of austerity', European Journal of Industrial Relations, 19:1, 71-86.

Howell, C. (2015), 'The changing relationship between labor and the state in contemporary capitalism', Law, Culture and the Humanities, 11:1, 6-16.

Howell, C. (2016), 'Regulating class in the neoliberal era: the role of the state in the restructuring of work and employment relations', Work, Employment and Society, 30:4, 573-89. 
Hyman, R. (2015), 'Three scenarios for industrial relations in Europe', International Labour Review 154:1, 5-14.

ILO (International Labour Organization) (2015a), Inventory of Labour Market Policy Measures in the EU 2008-2013: The Crisis and Beyond (Geneva: ILO), http:/ /www.ilo.org/wcmsp5/ groups/public/---dgreports/---inst/documents/publication/wcms_436119.pdf.

ILO (International Labour Organization) (2015b), Trends in Collective Bargaining Coverage: Stability, Erosion or Decline?, Policy Brief No. 1: Labour Relations and Collective Bargaining, ILO, www.ilo.org/global/topics/collective-bargaining-labour-relations/ publications/WCMS_409422/lang--en/index.htm, accessed 6 September 2016.

Ioannou, C. (2000), 'Social pacts in Hellenic industrial relations: Odysseus of Sisyphus?', in G. Fajertag and P. Pochet (eds), Social Pacts in Europe: New Dynamics (Brussels: European Trade Union Institute).

Ioannou C. (2012), 'Recasting Greek industrial relations: internal devaluation in light of the economic crisis and European integration', The International Journal of Comparative Labour Law and Industrial Relations, 28:2, 199-222.

Jaehrling, K. and Méhaut, P. (2013), 'Varieties of institutional avoidance: employers' strategies in low-waged service sector occupations in France and Germany', Socio-Economic Review, 11:4, 687-710.

Kahn-Freund, O. (1959), 'Labour law', in Ginsberg, M. (ed.) Law and Opinion in England in the 20th Century (Devon: Stevens).

Kanellopoulos, K. (2015), 'The effects of minimum wages on wages and employment', in Economic Bulletin, 41, Bank of Greece, Athens, 7-30.

Karamessini, M. (2012), 'Sovereign debt crisis: an opportunity to complete the neoliberal project and dismantle the Greek employment model', in S. Lehndorff (ed.), A Triumph of Failed Ideas: European Models of Capitalism in the Crisis (Brussels: European Trade Union Institute). www.etui.org/content/download/21029/175754/file/C8+12+A+triump $\mathrm{h}+$ of + failed+ideas+WEB.pdf.

Karamessini, M. (2015), 'The Greek social model: towards a deregulated labour market and residual social protection', in Vaughan-Whitehead, D. (ed.), The European Social Model in Crisis: Is Europe Losing its Soul? (Cheltenham: Edward Elgar and Geneva: International Labour Organization).

Koçer, R. G. and Visser, J. (2009), 'The role of the state in balancing the minimum wage in Turkey and USA', British Journal of Industrial Relations, 47:2, 349-70.

Koukiadaki, A. and Kokkinou, C. (2015), 'The Greek system of collective bargaining in (the) crisis, in Koukiadaki, A., Tavora, I. and Martinez Lucio, M. (eds), Joint Regulation and Labour Market Policy in Europe during the Crisis (Brussels: European Trade Union Institute).

Levin-Waldman, O. M. (2002), 'The minimum wage and regional wage structure: implications for income distribution', Journal of Economics, 36:3, 635-57.

McKnight, A., Duque, M. and Rucci, M. (2016), Creating More Equal Societies: What Works?, Evidence Review for DG Employment and Social Affairs (Brussels: European Commission).

Marginson, P. (2014), 'Coordinated bargaining in Europe: from incremental corrosion to frontal assault?', European Journal of Industrial Relations, 21:2, 97-114. 
O'Connor, J. (1973), The Fiscal Crisis of the State (New York: St Martin's Press).

OECD (Organisation for Economic Co-operation and Development) (2015), 'Recent Labour Market Developments with a Focus on Minimum Wages', Employment Outlook 2015 (Paris: OECD).

Rodgers, W. M., Spriggs, W. E. and Klein, B. W. (2004), 'Do the skills of adults employed in minimum wage contour jobs explain why they get paid less?', Journal of Post Keynesian Economics, 27:1, 38-66.

Rubery, J. (2003), Pay equity, minimum wages and equality at work (Geneva: International Labour Organization).

Schulten, T. (2012), 'European minimum wage policy: a concept for wage-led growth and fair wages in Europe', International Journal of Labour Research, 4:1, 85-104.

Sen, A. (1999), Development as Freedom (Oxford: Oxford University Press).

Stewart, M. B. (2012), 'Wage inequality, minimum wage effects, and spillovers', Oxford Economic Papers, 64:4, 616-34.

Streeck, W. (1997), 'Beneficial constraints: on the economic limits of rational voluntarism', in Rogers Hollingsworth, J. and Boyer R. (eds), Contemporary Capitalism: The Embeddedness of Institutions (Cambridge: Cambridge University Press), pp. 197-219. 